\title{
AMERICAN CUTANEOUS LEISHMANIASIS IN THE PONTAL OF PARANAPANEMA - SP, BRAZIL: ECOLOGICAL AND ENTOMOLOGICAL ASPECTS
}

\author{
Claudia Álvares Calvo ALESSI(1), Eunice Aparecida Bianchi GALATI(2), José Roberto ALVES(1) \& Carlos Eduardo Pereira CORBETT(3)
}

\begin{abstract}
SUMMARY
American cutaneous leishmaniasis (ACL) occurs in epidemic outbreaks and in sporadic cases with small annual variation in the Pontal of Paranapanema, SP. There is little research on the sandfly fauna of this region. The last outbreaks were related to the Movement of the Landless Workers (MST) and with the ecological tourism in preserved forest of the Parque Estadual do Morro do Diabo (PEMD). Aim: identification of the sandfly fauna within the PEMD, mainly anthropophilic species already incriminated as vectors of ACL, as well as their seasonality, hourly frequency and data of the behavior. M\&M: The captures were undertaken with CDC light and Shannon traps from 6:00 pm to 10:00 pm, monthly from May 2000 to December 2001. The temperature and relative humidity data were registered at hourly intervals. Results: The captured species were: Brumptomyia brumpti, Nyssomyia neivai, Nyssomyia whitmani, Pintomyia fischeri and Pintomyia pessoai. The P. pessoai predominated (34.39\%) and N. neivai was less found (0.74\%), only being captured in CDC traps. Shannon trap captured more sandflies $(63.01 \%)$ than the CDC traps (36.99\%). Despite the environmental degradation anthropophilic species, indicates favorable bioecological conditions for persistence of vectors and potential transmission of leishmaniasis.
\end{abstract}

KEYWORDS: American Cutaneous Leishmaniasis; Ecology; Phlebotominae; Brazil.

\section{INTRODUCTION}

American Cutaneous Leishmaniasis (ACL) is basically a zoonosis, caused by many species of protozoa of the genus Leishmania Ross, 1903 (Kinetoplastida, Trypanosomatidae) which is divided in two subgenera: Leishmania and Viannia (Lainson \& Shaw, 1987). The Leishmania parasites exist in two basic forms: the amastigote form in vertebrate host cells and the promastigote in the alimentary tract of the vector.

The clinical forms of the disease depend on the parasite species as well as the ecology of the area; therefore, the clinical picture of the disease presents a varied spectrum. The progress of the disease depends on the immune response of the host which determines the single ulcer, disseminated and diffuse cutaneous forms as also the destructive lesions in oral and nasal mucosa.

The vectors of the ACL are Phlebotominae (Diptera, Psychodidae). In Brazil, among the species considered as the main vectors of ACL, in accordance with GALATI's (2003) classification, are: Bichromomyia flaviscutellata, Migonemyia migonei, Nyssomyia umbratilis, Nyssomyia whitmani, Pintomyia pessoai and Psychodopygus wellcomei (DEDET, 1993; YOUNG \& DUNCAN, 1994; RANGEL \& LAINSON, 2003).
The vectors should be analyzed under two ecological aspects: in preserved forest and domiciliary environment. In the former, Leishmania transmission occurs between wild sandflies and mammals. The humans may be affected when they enter this environment, whether in the diurnal or nocturnal period. Near domiciliary areas the vectors may invade human houses, mainly at night.

In the São Paulo State about 60 sandfly species are known, 10\% of which are suspected of being vectors of ACL (GOMES, 1994). The Leishmania (Viannia) braziliensis is the species usually related to cutaneous leihsmaniasis in the São Paulo State. However, recently Leishmania (Viannia) guyanensis and Leishmania (Leishmania) amazonensis were identified in this region (data not shown).

The first cases of ACL reported in this state occurred in 1909 among workers who worked either in deforestation preparing land for agriculture or building railways in the northwest areas. The area after railway building is known as Pontal do Paranapanema.

In the fifties São Paulo State had again intense deforestation preparing for agricultural expansion, which changed the landscape. In the following decades, ACL appeared in epidemic outbreaks and in sporadic cases but with small variation in the annual frequency. Nowadays the situation has

(1) Unoeste, Oeste Paulista University, Presidente Prudente, SP, Brazil.

(2) University of São Paulo Faculty of Public Health, São Paulo, SP, Brazil

(3) University of São Paulo Medical School, São Paulo, SP, Brazil.

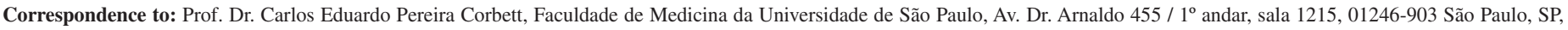
Brasil. Tel/fax: 55113081 7799. E-mail: ccorbett@usp.br 


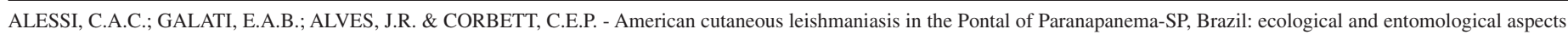
Rev. Inst. Med. trop. S. Paulo, 51(5): 277-282, 2009.

not changed; however, there is little research to improve the knowledge of the sandfly fauna of this region.

The last outbreak of ACL in the Pontal do Paranapanema occurred among rural workers belonging to the MST (Movement of the Landless Workers), a movement for agrarian reform for settlement in this area. It was also associated with the overture of an important ecological tourist center in a preserved forest area, the Parque Estadual do Morro do Diabo (PEMD), (FERNANDES, 2001).

The purpose of this study was to identify the sandfly fauna in an area within the PEMD, particularly the anthropophilic species already incriminated as vectors of ACL, as well as the seasonality, hourly frequency and data of the behavior of the vectorial species.

\section{MATERIAL AND METHODS}

Area of study: The Pontal do Paranapanema is situated in the southwest of São Paulo State, close to the confluence of the Paraná and Paranapanema rivers, on the border of the São Paulo, Mato Grosso do Sul and Paraná States. This region has an area of $8,936 \mathrm{~km}^{2}$ and covers 26 municipalities.

The physical characteristics of the soil of the Pontal do Paranapanema are determined by the presence of sandstone road. The area has warm weather, with a dry winter, an annual average temperature of $23{ }^{\circ} \mathrm{C}$ and an annual average relative humidity of between 70 and $76 \%$. The average annual rainfall is of $1,131 \mathrm{~mm}$, with a dry period from April to September. The prevailing winds came from east, followed by north and northeast, with an average speed $1.9 \mathrm{~m} / \mathrm{s}$. The economic activity of the area is mainly production of bricks and tiles and agriculture.

The first state park of the Pontal do Paranapanema, called the Forest Reserve of Morro do Diabo with an area of about 99,220 ha, was created in the late thirties. It suffered from destructive actions such as burning, deforestation and squatter trespassing over more than 45 years. The reserve now called State Park Morro do Diabo (PEMD), with area of 33,845 ha, situated in Teodoro Sampaio municipality ( $22^{\circ} 30^{\prime}$ LS and $52^{\circ} 20^{\prime}$ L.W; $350 \mathrm{~m}$ a.s.1.) was created in June 1986 (Figs. 1 and 2). The predominant vegetation is primary semideciduous seasonal forest, with some areas of secondary formation.

Entomological search: The sandfly collections were carried out in the southern part of the PEMD.

The captures were undertaken with CDC light and Shannon cotton traps from 6:00 pm to 10:00 pm, monthly during the period from May 2000 to December 2001 except for September 2000, March and October 2001 due to the heavy rains, totaling 68 hours per trap. Both traps were used in the same area.

The CDC trap was hung one meter above the ground.

Two investigators made the captures on the Shannon trap at hourly intervals, using tubes containing chloroform. The insects were kept in cardboard boxes for subsequent identification.

The data of the temperature and relative humidity, hygrometer, were

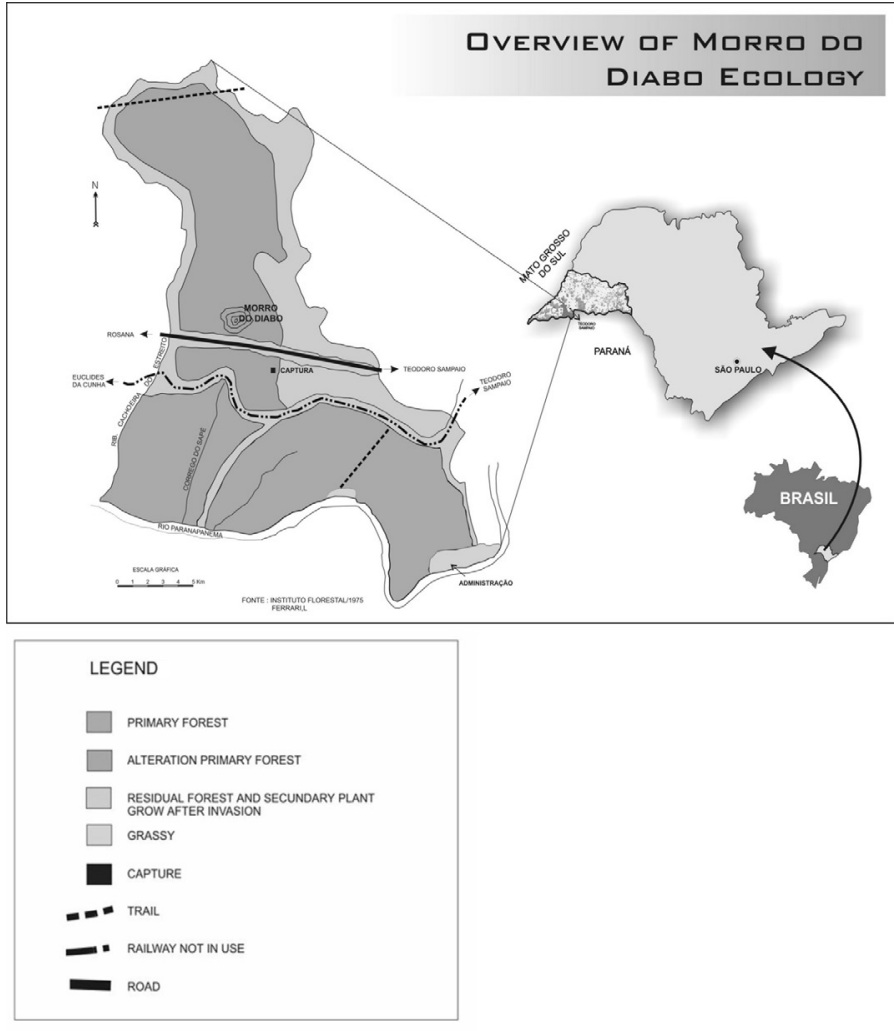

Fig. 1 - Overview of Morro do Diabo Ecology.

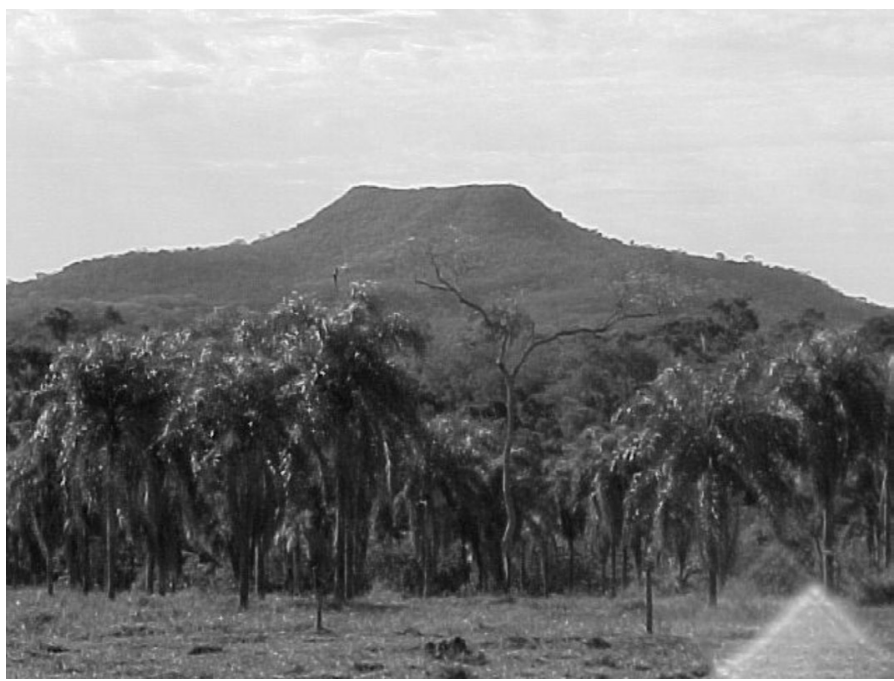

Fig. 2 - The hill called "Morro do Diabo" at the PEMD Ecological Reserve, semideciduous tropical forest.

registered at hourly intervals. The sandfly frequency was obtained by Williams' geometric average (HADDOW, 1954, 1960). (2003). 


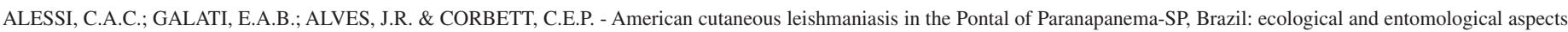
Rev. Inst. Med. trop. S. Paulo, 51(5): 277-282, 2009.

Table1

Sandflies captured by species, sex and traps in the wild ambient, in the PEMD, municipal district of Teodoro Sampaio, São Paulo State, during the period from May/2000, December/2001

\begin{tabular}{|c|c|c|c|c|c|c|c|c|}
\hline \multirow{2}{*}{ Species } & \multicolumn{3}{|c|}{ CDC } & \multicolumn{3}{|c|}{ Shannon } & \multirow{2}{*}{ Total } & \multirow{2}{*}{$\%$ species } \\
\hline & Male & Female & Subtotal & Male & Female & Subtotal & & \\
\hline Brumptomyia brumpti & 13 & 12 & 25 & 26 & 28 & 54 & 79 & $14.68 \%$ \\
\hline Pintomyia fischeri & 22 & 25 & 47 & 43 & 35 & 78 & 125 & $23.23 \%$ \\
\hline Pintomyia pessoai & 30 & 38 & 68 & 57 & 60 & 117 & 185 & $34.39 \%$ \\
\hline Nyssomyia whitmani & 29 & 26 & 55 & 48 & 42 & 90 & 145 & $26.95 \%$ \\
\hline Nyssomyia neivai & 3 & 1 & 4 & 0 & 0 & 0 & 4 & $0.74 \%$ \\
\hline Total & 97 & 102 & 199 & 174 & 165 & 339 & 538 & $100.00 \%$ \\
\hline
\end{tabular}

CDC Trap: $\chi^{2}-$ value $=1.086 \mathrm{GL}=3 \mathrm{p}$-value $=0.780 ;$ Shannon Trap: $\chi^{2}-$ value $=1.133 \mathrm{GL}=3 \mathrm{p}$-value $=0.769$

\section{RESULTS}

In the PEMD the following five phlebotomine species were captured: Brumptomyia brumpti (Larousse, 1920), Nyssomyia neivai (Pinto, 1926), Nyssomyia whitmani (Antunes \& Coutinho, 1939), Pintomyia fischeri (Pinto, 1926) and Pintomyia pessoai (Coutinho \& Barretto, 1940).

The total of sandflies collected with the CDC and Shannon traps is shown in Table 1: P. pessoai predominated (34.39\%) and N. neivai was the least numerous $(0.74 \%)$, only being captured in CDC traps. The total number of sandflies captured with the Shannon trap was greater $(63.01 \%)$ than that with all the CDC traps (36.99\%), this difference being statistically significant according to the $\chi^{2}$ test $(p<0.001)$; to both sexes of the other four species they were statistically significant more numerous on the Shannon traps than in all the CDC $(p<0.01)$; males of these species were statistically significant more numerous on Shannon than in all the CDC traps $(p<0.05)$; and the females though numerous on Shannon than the CDC, this difference was statistically significant $(p<0.05)$ only for B. brumpti and P. pessoai.

The analysis of the results will be restricted to the three most frequently captured species, the P. fischeri, P. pessoai and N. whitmani.

Figure 3 shows the seasonal variations of females and males of the three species over the year. Females of $N$. whitmani predominated in the winter of the two years, but in the other periods the averages were very low or close to zero. P. pessoai was more frequent in the autumn and spring but less so in the two winters. The $P$. fischeri occurred in lower density than the other species, but exceeded $N$. whitmani in the autumn. The seasonality of the males followed practically the same patterns as the females.

In the Figure 4 is plotted the hourly distribution on the Shannon trap of both sexes and females of the three prevalent species. Both sexes showed a peak in the third period (20-21h). Females of $P$. pessoai were practically constant in the first three periods, with a modest increase in the fourth period. $N$. whitmani and P. fischeri presented increasing frequencies, reaching a peak in the third period but decreasing in the fourth. Both traps were used in each area.

Figure 5 is the diagram of dispersion of the most frequent species, $P$. pessoai, $P$. fischeri and $N$. whitmani in relation to the relative humidity. For the three species the correlation coefficient $(\mathrm{R})$ was negative and
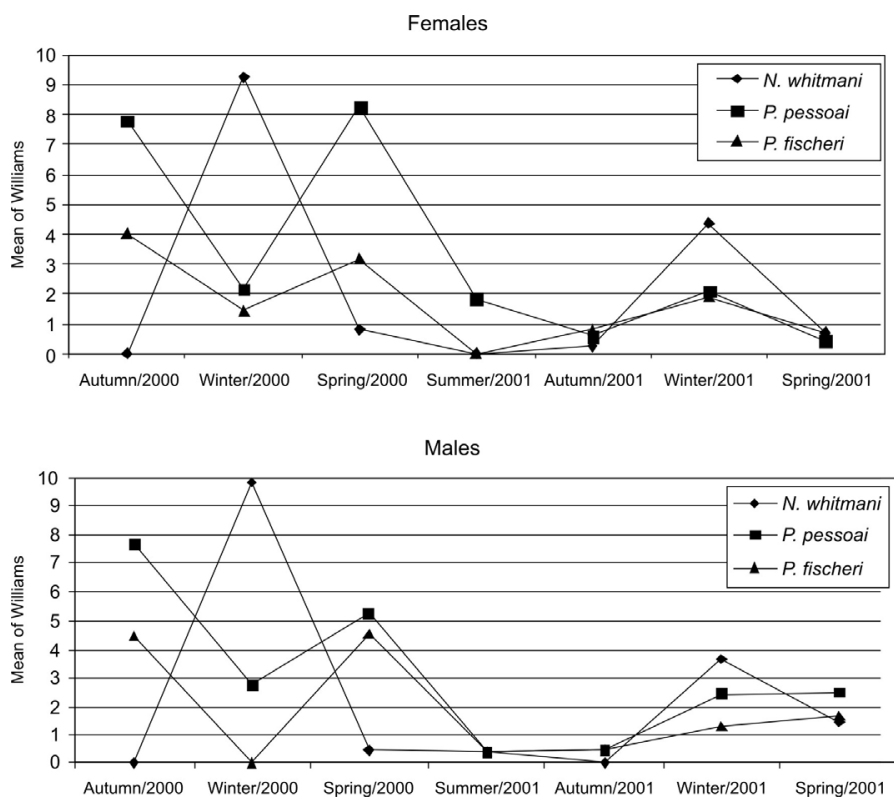

Fig. 3 - Seasonal distribution of captured females and males according to Williams' Geometric Mean.

was statistically significant at the $5 \%$ level ( $P$. pessoai, $\mathrm{R}=-0.587 ; p=$ $0.013 ;$ P. fischeri, $\mathrm{R}=-0.558 ; p=0.020$ and $N$. whitmani, $\mathrm{R}=-0.497, p$ $=0.043$ ). Despite the linear correlation, the dispersion diagram shows that an exponential adjustment may also provide good results in the modeling of the phenomenon.

No correlation between temperature variation and the number of sandflies captured was found (data not given).

The correlation diagram (Fig. 6) of the capture of females on the Shannon and CDC traps showed no linear relationship. The correlation coefficient was $\mathrm{R}=0.383 ; p=0.129$, not significant at the $5 \%$ level.

\section{DISCUSSION}

The five sandfly species captured (Table 1) had already been found in the São Paulo State. 

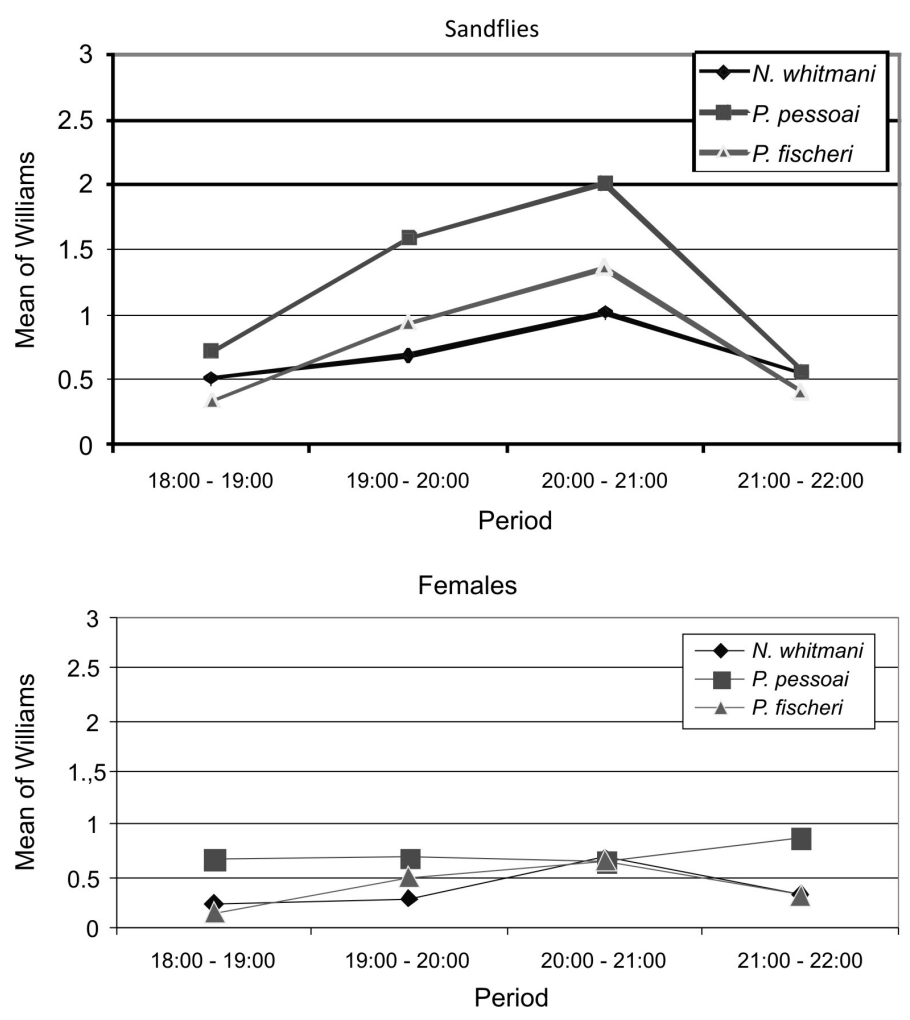

Fig. 4 - Hourly distribution of predominant sandflies in PEMD, during the period of 20 months.

The four most frequent species captured in this present study were also found by FORATTINI (1960) in the Alta Sorocabana region, in which the Pontal do Paranapanema was included, at that time, though with a predominance of N. neivai (63.39\%), followed by N. whitmani $(22.74 \%)$; P. pessoai $(8.14 \%)$ and $P$. fischeri $(2.83 \%)$. At that time $N$. neivai was denominated Phlebotomus intermedius, which had Phlebotomus neivai as its junior synonymous species; the differentiation between these two species was made by MARCONDES (1996) and only Ny. neivai occurred in that area (MARCONDES et al. 1998).

The three most frequent epidemiologically important species found in the present study were $P$. pessoai, $N$. whitmani and $P$. fischeri; which had also been observed with the same gradient by TEODORO et al. (1993) in the Paraná State, where $84.57 \%$ of the specimens identified belonged to $P$. pessoai, $N$. whitmani and $P$. fischeri. This prevalence may be due to the wild habitat of the species, which may live in forests as well as in deforested areas.

Despite the environmental degradation which had occurred in the area studied, the continued presence of the three above-mentioned species, clearly anthropophilic, indicates the persistence of favorable bioecological conditions for their survival. The transmissibility of the agent seems thus to have been maintained, though the potential transmission is much less than it was in the primary forest, thus leading to a reduced risk of human infection and of the incidence of cutaneous leishmaniasis in the area.

The results obtained with the two traps, the capture of females higher on the Shannon than in the CDC traps (Table 1), were similar to those

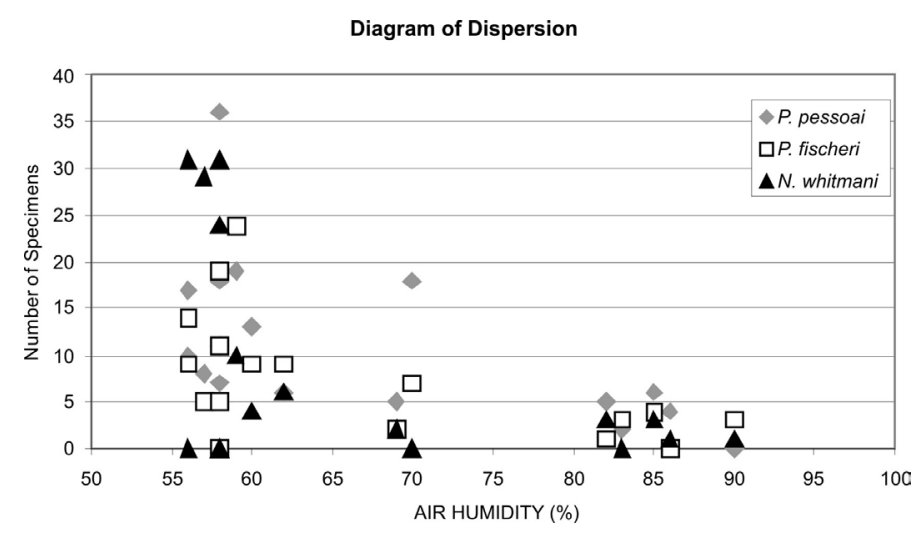

Fig. 5 - Diagram of dispersion of P. fischeri, P. pessoai and N. whitmani and relative humidity at the time of capture.

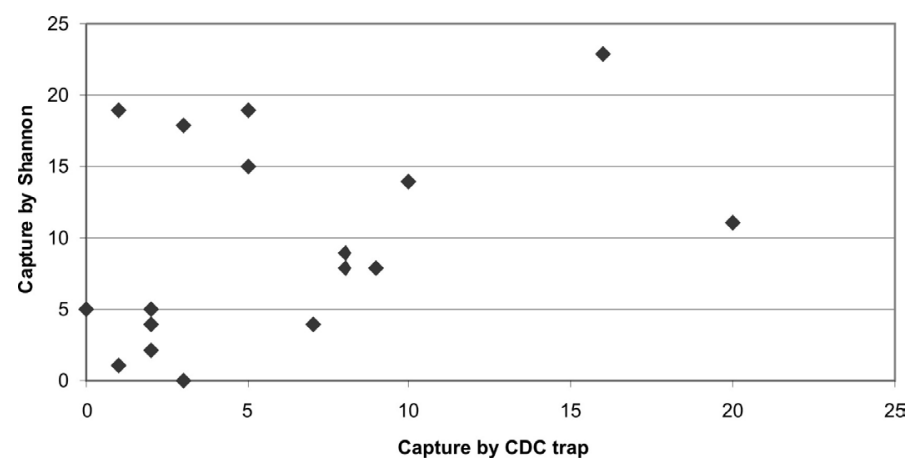

Fig. 6 - Diagram of the correlation to the captures of females (N. whitmani, P. pessoai, P. fischeri, B. brumpti and N. neivai).

obtained by LAINSON et al. (1994) in Amazonia; GOMES \& GALATI (1989) in the Ribeira river valley - SP; REBÊLO et al. (2000) in the Amazon region of Maranhão and GALATI et al. (1996) in Mato Grosso do Sul. However in the present study, the linear correlation coefficient was not significant at the $5.0 \%$ level.

In Corguinho municipality, Mato Grosso do Sul State, the seasonal pattern of L. whitmani, with peaks in the winter (GALATI et al. 1996), was similar to that found in the PEMD. The decrease in the number of specimens of L. whitmani captured in the summer and autumn was related to higher atmospheric humidity and the moderate winds when the captures were made, factors already recognized as interfering in the activity of the sandflies.

As regards the partial nocturnal rhythm of $N$. whitmani in the PEMD: it is similar to that observed by Galati et al. (1996), presenting peaks between 8:00 pm and 9:00 pm, suggesting that this period is the one which presents the highest risk of infection. In the São Paulo State its most intense activity occurred during the $3^{\text {rd }}$ hour after dusk (MAYO et al., 1998), whereas in the north of Paraná State, it occurred from 9:00 pm to 10:00 pm (TEODORO et al., 1993) and in the Bandeirantes municipality in the same state, from 8:00 pm to 10:00 pm (MASSAFERA et al., 2005). P. pessoai may be collected during the whole year, with peaks in the autumn and spring; these results differ from those observed by TEODORO et al. (1993) in the north of Paraná. P. pessoai is the most anthropophilic species, biting man 


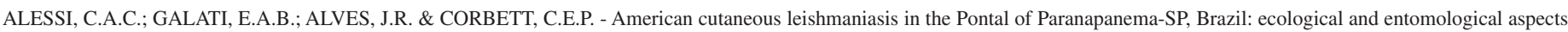
Rev. Inst. Med. trop. S. Paulo, 51(5): 277-282, 2009.

avidly. This suggests that the period after twilight offers a higher risk of infection.

There was no regular pattern of seasonal variation for $P$. fischeri. In spite of this, MAYO et al. (1998) demonstrated similar behavior and nocturnal rhythm. TEODORO et al. (1993) demonstrated the peak for $P$. fischeri in February, differently from the PEMD findings.

The point of view of GOMES \& GALATI (1989) that $N$. intermedia, $s$. lat. is capable of maintaining the human infection, replacing $N$. whitmani which is less adapted to altered forested environments, was not confirmed by our captures in the Pontal of Paranapanema, since $N$. neivai was captured less frequently $(0.74 \%)$. However, ODORIZZI \& GALATI (2007) obtained a very high frequency of this specie $(99.98 \%)$ in the forest on the banks of the Aguapei river, near Mirandópolis city in the northwestern region of São Paulo State, and in Bandeirantes municipality (PR) it was the second most frequent on the edge of the forest (MASSAFERA et al. 2005). Thus it seems that $N$. neivai is attracted by to the domiciliary environment and our captures of the species would have been greater if the captures had also been undertaken on the edge of the forest. The adaptation of the species involved in the ecology of the disease in forests modified by men, such as the known vectors for Leishmania (Viannia) braziliensis (LAINSON et al., 1981), i.e., P. pessoai, N. whitmani and P. fischeri, were found in the PEMD.

The presence of $P$. pessoai and $N$. whitmani suggests that the transmission of ACL in the forest in the Pontal of Paranapanema may still occur. However, the seasonal variation of the sandfly species in the PEMD was only characterized in one particular period.

The increase of the sandfly density at night, with the peak between 9:00 pm and 10:00 pm, indicates a higher risk of wild infection in natural hosts, thus maintaining the zoonosis in the PEMD. The man, as occasional host, is infected when he get into the forest during this period.

No interruption of transmission after devastation, such as was foreseen by PESSÔA \& BARRETO (1948), did in fact occur in large area of the São Paulo State; however, there is still a risk in residual forest areas.

\section{RESUMO}

\section{Leishmaniose cutânea americana no Pontal do Paranapanema, SP, Brasil: aspectos ecológicos e entomológicos}

LCA ocorre em surtos epidêmicos e casos esporádicos com pequena variação anual no Pontal do Paranapanema, SP. Há pouca pesquisa sobre a fauna flebotomínea na região.

Os últimos surtos estão relacionados ao MST e turismo ecológico na floresta do Parque Estadual do Morro do Diabo (PEMD). Objetivo: identificar a fauna flebotomínea no PEMD, principalmente as espécies antropofílicas já incriminadas como vetores da LCA, também, sua sazonalidade, horários e dados de comportamento. M\&M: As capturas foram feitas com armadilhas CDC e Shannon das 18 às 22h, mensalmente de maio de 2000 a dezembro de 2001. Dados de temperatura e umidade relativa foram registrados com intervalo de uma hora. Resultados: As espécies capturadas foram: Brumptomyia brumpti, Nyssomyia neivai, Nyssomyia whitmani, Pintomyia fischeri e Pintomyia pessoai. A $P$. pessoai predominou $(34,39 \%)$ e a $N$. neivai foi a menos encontrada
$(0,74 \%)$, capturada com a CDC. A Shannon capturou mais flebotomíneos $(63,01 \%)$ que a CDC (36,99\%). Apesar da degradação ambiental espécies, antropofílicas foram encontradas, indicando condições bioecológicas para persistência de vetores e potencial transmissão da leishmaniose.

\section{ACKNOWLEDGMENTS}

Supported by FAPESP, LIM-50 HC-FMUSP, UNOESTE PróReitoria de Extensão.

\section{REFERENCES}

1. DEDET, J.P. - Leishmania et leishmanioses du continent américain. Ann. Inst. Pasteur, 4: 3-25, 1993.

2. FERNANDES, B.M. - Questão agrária, pesquisa e MST. São Paulo, Editora Cortez, 2001. (Coleção Questões da Nossa Época, v. 92).

3. FORATTINI, O.P. - Sobre os reservatórios naturais da leishmaniose tegumentar americana. Rev. Inst. Med. trop. S. Paulo, 2: 195-203, 1960.

4. GALATI, E.A.; NUNES, V.L.B.; DORVAL, M.E.C. et al. - Estudos dos flebotomíneos (Diptera, Psychodidae) em área de leishmaniose tegumentar, no Estado de Mato Grosso do Sul, Brasil. Rev. Saúde públ. (S. Paulo), 30: 115-128, 1996.

5. GALATI, E.A.B. - Classificação de Phlebotominae. In: RANGEL, E.F. \& LAINSON, R., org. Flebotomíneos do Brasil. Rio de Janeiro, Editora FIOCRUZ, 2003. p. 23-51.

6. GOMES, A.C. - Sand fly vectorial ecology in the State of São Paulo. Mem. Inst. Oswaldo Cruz, 89: 457-468, 1994.

7. GOMES, A.C. \& GALATI, E.A.B. - Aspectos ecológicos da leishmaniose tegumentar americana. 5. Estratificação da atividade especial e estacional de Diptera, Psychodidae em área de cultura agrícola da região do Vale do Ribeira, Estado de São Paulo, Brasil. Mem. Inst. Oswaldo Cruz, 82: 467-473, 1987.

8. GOMES, A.C. \& GALATI, E.A.B. - Aspectos ecológicos da leishmaniose tegumentar americana. 7. Capacidade vetorial flebotomínea em ambiente florestal primário do sistema da Serra do Mar, região do Vale do Ribeira, Estado de São Paulo, Brasil. Rev. Saúde públ. (S. Paulo), 23: 136-142, 1989.

9. HADDOW, A.J. - Studies on the biting habits of African mosquitoes: an appraisal of methods employed, with special reference to the twenty-four hour catch. Bull. Entomol. Res., 45: 199-242, 1954

10. HADDOW, A.J. - Studies on the biting habits and medical importance of east African mosquitoes in the genus Aedes. I. Subgenera Aedimorphus, Banksinella and Nunnius. Bull. Entomol. Res., 50: 759-779, 1960.

11. LAINSON, R.; SHAW, J.J.; READY, P.D.; MILES, M.A. \& PÓVOA, M. Leishmaniasis in Brazil. XVI. Isolation and identification of Leishmania species in North Pará State, with particular reference to Leishmania braziliensis guyanensis causative agent of "pian bois". Trans. roy. Soc. trop. Med. Hyg., 75: 530-536, 1981.

12. LAINSON, R. \& SHAW, J.J. - Evolution, classification and geographical distribution. In: PETER, W. \& KILLICK-KENDRICK, R., ed. The leishmaniasis in Biology and Medicine. London, Academic Press, 1987. v. 1, p. 1-120.

13. LAINSON, R.; SHAW, J.J.; SILVEIRA, F.T. et al. - The dermal Leishmaniases of Brazil, with special reference to the eco-epidemiology of the disease in Amazônia. Mem. Inst. Oswaldo Cruz, 89: 435-443, 1994.

14. MARCONDES, C.B. - A redescription of Lutzomyia (Nyssomyia) intermedia (Lutz \& Neiva, 1912), and resurrection of L. neivai (Pinto, 1926) (Diptera, Psychodidae, Phlebotominae). Mem. Inst. Oswaldo Cruz, 91: 457-462, 1996. 
ALESSI, C.A.C.; GALATI, E.A.B.; ALVES, J.R. \& CORBETT, C.E.P. - American cutaneous leishmaniasis in the Pontal of Paranapanema-SP, Brazil: ecological and entomological aspects. Rev. Inst. Med. trop. S. Paulo, 51(5): 277-282, 2009.

15. MARCONDES, C.B.; LOZOVEI, A.L. \& VILELA, J.H. - Distribuição geográfica de flebotomíneos do complexo Lutzomyia intermedia (Lutz \& Neiva, 1912) (Diptera, Psychodidae). Rev. Soc. bras. Med. trop., 31: 51-58, 1998.

16. MASSAFERA, R.; SILVA, A.M.; CARVALHO, A.P et al. - Fauna de flebotomíneos (Diptera: Psychodidae) do município de Bandeirante, no estado do Paraná, sul do Brasil. Rev. Saúde públ. (S. Paulo), 39: 571-577, 2005.

17. MAYO, R.C.; CASANOVA, C.; MASCARINI, L.M. et al. - Flebotomíneos (Diptera, Psychodidae) de área de transmissão de leishmaniose tegumentar americana, no município de Itupeva, região sudeste do Estado de São Paulo, Brasil. Rev. Soc. bras. Med. trop., 31: 339-345, 1998.

18. ODORIZZI, R.M.F.N. \& GALATI, E.A.B. - Flebotomíneos de várzea do rio Aguapeí, região noroeste do Estado de São Paulo. Rev. Saúde públ. (S. Paulo), 41: 645-652, 2007.

19. PESSÔA, S.B. \& BARRETO, M.P. - Leishmaniose tegumentar americana. Rio de Janeiro, Imprensa Nacional, 1948.
20. RANGEL, E.F. \& LAINSON, R. - Ecologia das leishmanioses. In: RANGEL, E.F. \& LAINSON, R., org. Flebotomíneos do Brasil. Rio de Janeiro, Editora FIOCRUZ, 2003. p. 291-309.

21. REBÊLO, J.M.M.; OLIVEIRA, S.T.; BARROS, V.L.L. \& SILVA, F.S. - Flebotomíneos da Amazônia Maranhense. IV. Riqueza e abundância relativa das espécies em área de colonização antiga. Entomol. Vect., 7: 61-72, 2000.

22. TEODORO, U.; LA SALVIA FILHO, V.; de LIMA, E.M. et al. - Observações sobre comportamento de flebotomíneos em ecótopos florestais e extraflorestais, em área endêmica de leishmaniose tegumentar americana, no norte do Estado do Paraná, sul do Brasil. Rev. Saúde públ. (S. Paulo), 27: 242-249, 1993.

23. YOUNG, D.G. \& DUNCAN, M.A. - Guide to the identification and geographic distribution of Lutzomyia sand flies in Mexico, the West Indies, Central and South America (Diptera: Psychodidae). Gainesville, Associated Publishers, 1994.

Received: 4 May 2009

Accepted: 24 July 2009 